\title{
Meister Eckhart and Jan Van Ruusbroec: A Comparison
}

\author{
RIK VAN NIEUWENHOVE \\ Trinity College, Dublin
}

Jan Van Ruusbroec (1293-1381), the most important spiritual writer of the Low Countries, is often associated (with or without some qualifications) with the tradition of the Rhineland Mystics, of which Meister Eckhart (c. 1260-1327) is the most prominent exponent. ${ }^{1}$ To date however, an in-depth study of the influence of Meister Eckhart's main doctrinal positions on Ruusbroec's thought has not been published. ${ }^{2}$ In this paper I want to compare their central ideas concerning the relation between God and his creation (in particular man). More specifically, I hope to make clear that the vocabulary they occasionally share (Birth of the Son in the soul, the spark of the soul, the ground of the soul, the soul as Image, and so on) actually veils two very different theologies.

Although I do not aspire to originality in presenting Eckhart's thought, I am aware that a presentation of his challenging doctrine is already an interpretation itself. I will use a text from Aquinas's Summa Theologiae to unlock his thought. ${ }^{3}$ Eckhart emphasizes both the fundamental dependence of creatures on God and the absolute otherness of God whereby he radicalizes the traditional teaching (to be found in Thomas Aquinas) that creatures are like God but that God is unlike his creation. Thus Eckhart can state that God as intellect is beyond being and that being is God; that God should not be called "good" and that creatures insofar as they are good, are God, and so on.

I would like to thank Dr. Lewis Ayres, Trinity College, Dublin, for useful comments and helpful criticism of an earlier draft of this article.

1. For instance O. Davies, The Rhineland Mystics: An anthology (London: SPCK, 1989); O. Davies, God Within: The mystical Tradition of Northern Europe (London: Darton, Longman \& Todd, 1988). L. Cognet, Introduction aux mystiques rhénoflamands (Paris: Desclée, 1968).

2. E. Colledge and J. C. Marler, "Poverty of the Will': Ruusbroec, Eckhart and The Mirror of Simple Souls," Jan Van Ruusbroec: The Sources, Content and Sequels of His Mysticism, ed. P. Mommaers and N. De Paepe (Leuven: Leuven University Press, 1984), p. 14-47 is a possible exception, although the article focuses primarily on the influence of Marguerite Porete on Eckhart and Ruusbroec and only secondarily on the relation between Eckhart and Ruusbroec.

3. ST I. 4.3 ad 3. 
Following this, I will focus on Eckhart's doctrine of the Trinity and its close connection to his understanding of creation (bullitio and ebullitio), his negative anthropology and more in particular, in section two of the first Part, his theology of the Image (with a particular focus on the role of the intellect) which offers an interesting starting point for a comparison with Ruusbroec.

The second part of this article sketches Ruusbroec's trinitarian doctrine, with a special emphasis on the role of the Spirit as an active principle of regyratio. I will try to indicate Ruusbroec's indebtedness to and divergence from Bonaventure so as to highlight the originality of the approach of the Flemish Prior. In a second section of the part dealing with Ruusbroec, I will explore his theology of the Image in the course of which his distinct approach will become evident.

It will transpire that Ruusbroec's thought differs radically in inspiration and nature from that of Eckhart in almost each doctrinal area: trinitarian doctrine (no Godhead beyond the divine Persons; emphasis on Spirit as active principle of regyratio), christology and soteriology (distinctive emphasis, absent in Eckhart's writings, on the life and humanity of Christ whose mission has to be seen in the light of the nature of Love as do ut des), theology of grace and sacramental theology (Ruusbroec draws a clear distinction between God's creative and re-creative activity and stresses the need for grace made available in the sacraments, especially in the Eucharist), anthropology (memory, not intellect as ground of the soul; no connaturality between divine and human intellect), and the like.

It may surprise some readers that I consider Ruusbroec a theologian. Indeed, contrary to what some scholars presume, I take for granted that Ruusbroec is more than merely a "mystical writer" or even "a phenomenologist of the mystical experience," 4 but rather a spiritual writer who has an important and original theological contribution to make. I trust this text will demonstrate the accuracy of this presupposition.

\section{MEISTER ECKHART}

\section{A. A General Outline of Meister Eckhart's Doctrine}

A key problem in the interpretation of Eckhart's thought is the way he understands the relation between God and creatures. On the one hand, he affirms the radical otherness of God in often colourful language: "God is

4. This is how P. Mommaers characterises Ruusbroec. Mommaers's work is a typical example of the tendency to focus on mystical "experience" separate from the broader theological framework. Such an approach is indebted to W. James's The Varieties of Religious Experience. A Study in Human Nature, first published in 1902. See Mommaers's latest book, with J. Van Bragt: Mysticism Buddhist and Christian. Encounters with Jan Van Ruusbroec (New York: Crossroad, 1995). 
not 'good', or 'better' or 'best'. Whoever should say God is good would do him as much injustice as if he were to call the sun black."5 Elsewhere however he seems to assert the identity of creaturely and divine perfections: the good man, insofar as he is good, is "unmade and uncreated." "That which is good and goodness are nothing else than one single goodness in everything, apart from the one bearing and the other being born." 6

How can Eckhart say that God is totally unlike his creation and claim at the same time that creaturely perfections are so dependent on God to the point where they appear to become identical to the divine perfections? In my opinion an article from Thomas Aquinas's Summa Theologiae can throw some light on this problem.

\begin{abstract}
Although it may be admitted that creatures are in some sort like God, it must nowise be admitted that God is like creatures; because, as Dionysius says (Div. Nom. ix): "A mutual likeness may be found between things of the same order, but not between a cause and that which is caused." For, we say that a statue is like a man, but not conversely; so also a creature can be spoken of as in some sort like God; but not that God is like a creature. ${ }^{7}$
\end{abstract}

Eckhart seems to exploit the poles of this one-sided relation in an extreme manner that results in a significant divergence from Thomas's theology. In what follows I will first clarify one pole of this assertion, namely that God as understanding or intellect is radically different from his creation. ${ }^{8}$ Then I will deal with the second pole of the assertion, namely the strict unity between creation and God (being as God) which results in what I will call a relation of "asymmetric identity" between creatures and God.

A.1. The primacy of Intellect: Deus est Intelligere The main thesis of the Parisian Questions is that God does not think because He is, but He is

5. Sermon 9 following J. Quint's numbering in the edition of the German works as translated by M. O'C. Walshe, Meister Eckhart Sermons E ${ }^{\circ}$ Treatises, Vols. I \& II, (Element Books, 1987). Henceforth W.I and II: W.II. p. 151.

6. The Book of "Benedictus," trans. E. Colledge, from B. McGinn and E. Colledge: Meister Eckhart. The Essential Sermons, Commentaries, Treatises, and Defense Classics of Western Spirituality (New York: Paulist Press, 1981). Henceforth: McGinn I. p. 210.

7. ST I.4.3 ad 3, trans. Fathers of the English Dominican Province, 5 vols. (Westminster, Christian Classics, Md.: 1981). See also ST I.13.7.

8. It is notoriously difficult to translate accurately the medieval concepts intelligere and intellectus. It is little comfort that the confusion dates from the Middle Ages themselves; to give a well-known example: the Augustinian intellectus, voluntas, and memoria were understood by Peter Lombard to refer to faculties-an interpretation rejected by Thomas in the Summa (ST I.93.7 ad 3). Eckhart describes God in terms of intelligere or intellectus without any significant differences, which seems to indicate that he too prefers a more dynamic reading, such as "understanding": "natura Dei est intellectus, et sibi esse est intelligere." (Comm. Gen. no. 11). On the other hand, it cannot be denied that he attributes Aristotelian characteristics to man's intellectus which, he argues, it shares with God (see n.14). 
because He thinks. Although Eckhart does not deny that understanding is a form of existence, he claims that understanding is superior to existence and belongs to a different order. ${ }^{9}$ The Meister refers to the Prologue to John's Gospel ("In the beginning was the Word, and the Word was God"; John does not say "being") and the fourth proposition of the Book of Causes which says that the first of created things is being. ${ }^{10}$ In short, God is intellect or understanding, not being or existence (non ens vel esse). He is uncreated understanding beyond being, the foundation of being.

Furthermore, a cause has to differ essentially from its effect, for if it did not it would not make sense to speak of cause and effect (they would be essentially the same). ${ }^{11}$ Seeing that God is the cause of creation, that is, of being, there cannot be any being (createdness) in God: "Nothing is formally in both a cause and its effect if the cause is a true cause. Now God is the cause of all existence. It follows that existence is not formally present in God."12 Certainly, this safeguards God's transcendence, but the relation between God and creatures appears to become problematic, although we need to make an important qualification, namely with respect to the relation between God and man.

Aristotle had argued in Book III of De Anima that for thinking to occur the intellect has to be universal, separated from matter and incorporeal. ${ }^{13}$ These characteristics it shares with God. Thus, the metaphysical statement that God is intellect has both epistemological connections (indeterminate thinking can think the forms of all determinate things) and spiritual significance: the intellect has nothing in common with created beings. Man, insofar as he is intellect, is therefore indistinguishable from God. This explains Eckhart's intellectualism, which represents both a continuation and a radicalization of Thomas's. This isomorphy between the divine and the human intellect is therefore the foundation of our deification:

From what has been said you can understand the way in which one "who adheres to God is one spirit" (1Cor. 6:17). Intellect properly belongs to God, and "God is one." Therefore, anything has as much of God and the One and of "One-Existence" with God as it has of intellect and what is intellectual. For God is one intellect and intellect is one. Nowhere and never do we find God as God save in intellect. . . . Rise

9. A. Maurer, Master Eckhart. Parisian Questions and Prologues (Toronto: Pontifical Institute of Mediaeval Studies, 1974), p. 46.

10. "The first of created things is being, and there is nothing else created before it." For an English translation of Liber de Causis: The Book of Causes, trans. from the Latin with intro. by D. J. Brand (Milwaukee: Marquette University Press, 1984).

11. Par. Quest. 2.10.

12. Par. Quest. 1.8; A. Maurer, Master Eckhart, p. 48.

13. De Anima, 429a 24-25. The mind is unmixed not only with body but with any form whatsoever, in order that, having no character of its own, it can take on the forms without distortion in the act of thinking. 
up then to intellect; to be attached to it is to be united to God. To be united, to be one, is to be one with God. ${ }^{14}$

The human intellect is the only avenue open to man to attain to the Otherness of God. Below we will investigate the nature of the intellect and its relation to God in more detail ("the spark of the soul"), but first we need to explore the other pole in Eckhart's thought, namely the dependence of creatures on God.

A.2. Esse Deus est According to the Parisian Questions, creatures receive their being from God, who is himself beyond being, as thought, for there is no essential connection between cause and effect (a Neoplatonic principle which will be compared below with Thomas's treatment of the same subject). With such a notion of causality, Eckhart is able to argue that insofar as creatures have being, God is not, or, insofar as God is, creatures are nothing. The latter is a recurring statement in the German works and was condemned by the papal bull "In agro domenico" (1329).

In the Three-Part Work, Eckhart argues that being is God. This has sometimes been interpreted as "God is being," a widespread assertion in the Middle Ages, and one that Eckhart himself makes on numerous occasions. Understood in this way, it could be argued that there is no contradiction between saying that God is intellect and God is being, for in the latter case God's being is clearly distinguished from created being: esse indistinctum, esse simpliciter versus esse hoc et hoc, esse formaliter inhaerens (if God is being, creatures are nothing, and vice versa). 15 Throughout the Latin and German works there can be found a multitude of references to God as undifferentiated existence, qualified by frequent appearances of texts asserting that God is in some way beyond esse. ${ }^{16}$ However, O. Davies, following a suggestion by Karl Albert, has pointed out that Esse est Deus is a statement of predication and not of identity: it should therefore be distinguished from the phrase "God is being." 17 If this view is correct, Eckhart is asserting something about creation, and in particular, its radical dependence on God. Apart from God, creatures are absolutely nothing, and therefore, whatever perfections they have, they have from God:

All creatures are pure nothing. I do not say they are a trifle or they are anything: they are pure nothing. What has no being, is not. All creatures have no being for their being consists in the presence of God.18

14. Sermon XXIX, no. 304, B. McGinn, ed. with collaboration of F. Tobin and E. Borgstadt, Meister Eckhart Teacher and Preacher. Classics of Western Spirituality (New York: Paulist Press, 1986). Henceforth, McGinn II p. 226.

15. See B. McGinn's "Theological Summary" of Eckhart's theology in McGinn I, p. 33.

16. McGinn I p. 32 plus refs. p. 300 n. 44-45.

17. O. Davies, Meister Eckhart. Mystical Theologian (London: SPCK, 1992), p. 108, following K. Albert, Meister Eckharts These vom Sein: Untersuchingen zur Metaphysik des Opus Tripartitum (Saarbrücken: Universitäts-und Schulbuchverlag, 1976), p. 38.

18. Sermon 4, W.I, p. 284. 
In his Second Lecture on Ecclesiasticus, Eckhart, commenting on Si.24:29, observes that every being, in that it is empty in and of itself, thirsts for and desires existence itself; it is more proper to say that something continually receives existence rather than that it has existence itself in a fixed way. He illustrates his meaning by referring to light and heat in a medium: while heat takes root in the medium and remains fixed after the sun has set, light does not and departs from the air when the sun has gone down, "because it has not the slightest root in the form it accompanies, but only a thirst or appetite."19 This comparison illustrates the radical dependence of the creature on God, namely that

what it possesses it does not have from itself as something that inheres in it, but that it has begged it and received it as something that is continually on loan. It has it in passing, as a reception, and not like a received quality given by its superior cause. ${ }^{20}$

This sort of language has led O. Davies to argue that this second approach (being is God) entails univocal usage of terms as applied to God and creation. Seeing that creatures are nothing in themselves, their perfections are really God's perfections (with the proviso that in God they are actualized in an infinite manner) and predication of them is therefore univocal:

The clear statement that "being is God" indicates that Eckhart's application of the word 'being' to both God and creatures is univocal (has the same meaning), and that the distinction between God and his creation is maintained by the fact that the being of God is infinite while that of creatures is finite and particular. This is thoroughly consistent with the inquantum principle of Eckhart's theory of analogy. ${ }^{21}$

Although it can be doubted whether it is justifiable to call the application of "being" to both God and creatures "univocal," if it is granted that being in God is infinite and simple, while in creatures it is finite and particular, there appear to be sufficient passages in support of such an interpretation, especially those where Eckhart draws a close parallel between the generation of the Son and creation (and the "generation" of the just man in particular). ${ }^{22}$ In the Parisian Questions it was argued that God is beyond being because cause and effect have to differ essentially. However, it is not because the Cause differs essentially from its effects that therefore the effects cannot be similar (or even identical, according to some of Eckhart's most radical assertions) to their Cause. We could call this "asymmetric identity" between creation and God. On numerous occasions Eck-

19. Comm. Ecc. no. 46, McGinn II, pp. 175-176.

20. Par. Gen. no. 25, McGinn I, p. 103.

21. Davies, Meister Eckhart, p. 109.

22. See n.61 and the quotation in the main text. 
hart emphasizes this one-sided dependence of creatures on God: "a superior in itself always affects its inferior and, vice versa, is in no way affected by it," ${ }^{23}$ while in Sermon 71 we read: "God flows into all creatures, and yet remains untouched by them all. He has no need of them." 24 Elsewhere he uses a famous illustration, speaking of the deified soul: "If you were to cast a drop into the ocean, the drop would become the ocean, not the ocean the drop." 25

Esse Deus est and similar statements say something about creation's radical dependence on God and not about God as such and need therefore to be distinguished from statements like Deus est intelligere or Deus est esse (absolutum). Once this different perspective is grasped, it will become clear how Eckhart can consistently affirm that man is good in the same way as God is good, and yet claim that calling God good is an injustice. "Being is God" implies that being does not exhaust (the concept of) God; therefore, it is not incompatible to say that God is intellect or understanding. ${ }^{26}$ Whereas in the Parisian Questions the position that God is intellect was argued on the basis of a notion of essential dissimilarity between cause and effect, saying that "being is God" does not contradict this notion of causality, for God transcends being, while at the same time bestowing it upon creatures who are nothing in themselves without this continual gift. In short, Deus est intelligere (and therefore not particular being) says something about the transcendent God, while Esse est Deus says something about creatures and their dependence on God. When Eckhart calls God being, ${ }^{27}$ he is careful to indicate the difference between God as absolute being and creaturely or particular being: esse absolutum versus esse formaliter inhaerens. 28

Eckhart's distinctive use of analogy hints at the same dynamic of asymmetric identity as becomes clear from an oft-misunderstood passage:

Being or existence and every perfection, especially general ones such as existence, oneness, truth, goodness, light, justice, and so forth are used to describe God in an analogical way. It follows from this that goodness and justice and the like (in creatures) have their goodness totally from something outside to which they are analogically ordered, namely God. . . . Analogates have nothing of the form according to which they are analogically ordered rooted in positive fashion in themselves. But every created being is analogically ordered to God in exist-

23. Comm.Wis. no. 39, McGinn II p. 155. A similar passage is to be found in Comm. Jn. no. 555 where Eckhart refers to Macrobius. McGinn II, p. 185.

24. Sermon 71, W.I, p. 155

25. Sermon 80, W.II, p. 323.

26. If this is a statement of predication, this implies that the predicate has a wider range of application than the subject. One can say that Dominicans are humans, but one cannot say that humans are Dominicans.

27. There is no reason to consider this "an emphatic inversion," (Davies, Meister Eckhart, referring to K. Albert, p. 122 n.22.)

28. McGinn I, p. 33. 
ence, truth and goodness. Therefore every created being radically and positively possesses existence, life and wisdom from and in God, not in itself as a created being. ${ }^{29}$

Unlike some commentators who hold the view that Eckhart argues here for the radical gulf between creatures and God-according to Tobin, it would be a case of "extrinsic analogy"-I think it is safe to assume that Eckhart stresses here the radical dependence of creatures on God (identity of creaturely and divine perfections): the perfections creatures have are divine perfections, for in themselves creatures have nothing-whatever they have they have from God:

the one and the same health that is in the animal [the perfections that exist in God] is that (and no other) which is in the diet and the urine [perfections as found in creation] in such a way that there is no more of health as health in the diet and urine than there is in a stone [creatures do not have any perfections "of their own"]. .30

A closer comparison will show how Eckhart radicalizes Thomas Aquinas's position. Because Thomas emphasizes the autonomous nature of creatures more than Eckhart who on the contrary stresses their radical nothingness, the German Dominican has to conclude that creatures insofar as they "have" being, goodness etc., are God's goodness, being. In ST Ia.4.3 ("Whether any creature can be like God"), Aquinas invokes his principle of analogy: seeing that God is not contained in any genus the effects will only distantly reproduce the form of the agent. It is interesting to observe that Thomas, while referring to Dionysius in the reply to the objections, ${ }^{31}$ opts for an Aristotelian principle in the corpus of the article, namely that since every agent reproduces itself so far as it is an agent, and everything acts according to the manner of its form, the effect must in some way resemble the form of the agent. ${ }^{32}$ Obviously, I do not want to suggest that Eckhart (who, as we have seen, refers to a Neoplatonic principle to account for the [dissimilar] relation between cause and effect) is a Neoplatonist and Thomas an Aristotelian, but I merely want to indicate the multifarious appropriation of Neoplatonism by Eckhart and Thomas.

29. Comm.Ecc. no. 52-53, McGinn II, p. 178

30. For a different interpretation, see F. Tobin, Meister Eckhart: Thought and Language (Philadelphia: University of Pennsylvania Press, 1986). Davies's comments on this passage are helpful, pp. 103-7.

31. STIa.4.3 ad 4. See n.8 and the quotation of this reply in the main body of text

32. ST Ia.4.3. The fact that Thomas uses an Aristotelian principle on this crucial issue-the relation between the Creator and his creation-should arouse suspicion of an exclusively Neoplatonic reading of Aquina's Summa. On the other hand, Thomas's indebtedness to the Neoplatonic tradition is a well-documented: see W. J. Hankey, God in Himself: Aquinas Doctrine of God as Expounded in the Summa Theologiae (Oxford: Oxford University Press, 1987), and F. O'Rourke, PseudoDionysius and the Metaphysics of Aquinas. (Leiden, 1992). 
Because Thomas emphasizes the relative autonomy of creation, he is in a position to argue that the effects resemble their Cause, whereas Eckhart who stresses the nothingness of creatures has to conclude that creaturely perfections are actually divine perfections-without wanting to imply that God is similar to his creation. Thomas offers a similar correction to the assertion that the first Cause is beyond being in his Commentary on the Book of Causes: for Thomas "to be" is not simply the primary effect caused by God as Creator but God's essence, and so God's proper name. ${ }^{33}$ Of course, I do not want to suggest that Thomas somehow blurs the distinction between the divine being and esse commune, for he clearly distinguishes them. ${ }^{34}$ Yet, Eckhart's different understanding of the status of creation results in a very different concept of analogy and, as I will explain below, a particular theology of grace.

If the Parisian Questions emphasized the transcendence of God, and the Opus Tripartitum his immanence, or rather the dependence of creatures on God, it is revealing how Eckhart combines both perspectives: by emphasizing God's transcendence (esse absolutum or indistinctum) Eckhart can at the same time stress his immanence and vice versa. In his Commentary on Exodus no. 113-14 and Commentary on Wisdom no. 154-55, Eckhart argues that the transcendent nature of God (his indistinct character) does not allow us to distinguish him from particular, created beings. Seeing that one can only distinguish between things that have something in common and God does not even have being in common with the particular beings of His world, He cannot be distinguished from them, or rather, His indistinctive nature (esse indistinctum) itself is the way in which He can be "distinguished" from distinctive beings (esse hoc et hoc). Thus, if indistinction is the basis for distinction, then it follows that the more you emphasize God's similarity, the more you implicitly stress his dissimilarity and vice versa. It places Eckhart squarely in the tradition of negative

33. See the "Introduction" by V. A. Guagliardo to St. Thomas Aquinas: Commentary on the Book of Causes, trans. V. A. Guagliardo, C. Hess, and R. C. Taylor, (Washington D.C. The Catholic University Press of America Press, 1996), p. xxviii n.6. According to Thomas, "the first cause is above being inasmuch as it is itself infinite "to be" (esse). "Being" (ens), however, is called that which finitely participates "to be", and it is this which is proportioned to our intellect" (p. 51).

34. STIa $3.4 \mathrm{ad} 1$. Nevertheless, Thomas is more nuanced and always more moderate than Eckhart when it comes to describing how God relates to His creation. Whereas Eckhart clearly states that God is completely and utterly unlike His creation, Thomas writes it is "more fitting" to say that a creature is like God than the converse. Likening the relation between God and His creatures to that of the sun and its effects, he surprisingly writes: "And so the sun is said to be somewhat like those things in which it produces its effects as an efficient cause. Yet the sun is also unlike all these things in so far as such effects do not possess heat and the like in the same way as they are found in the sun. So, too, God gave things all their perfections and thereby is both like and unlike all of them" (Summa contra Gentiles I.29, trans. A. Pegis Notre Dame, Ind.: University of Notre Dame Press, 1975), p. 138. 
theology: the more "appropriate" predications are, the less they actually apply to God. 35

The distinction between God and creatures is therefore based on the "indistinct" character of being (esse indistinctum). Before we explore Eckhart's trinitarian thought and its relation to his doctrine of creation, it is interesting to observe that "Unum" can serve the same purpose, as we learn from his Commentary on Wisdom (Ws. 7:27a): "the term "one" is the same as indistinct, for all distinct things are two or more, but all indistinct things are one. Furthermore, there is an indistinction that concerns God's nature, both because $\mathrm{He}$ is infinite and also because $\mathrm{He}$ is not determined by the confines or limits of any genera or beings. But it is the nature of any created being to be determined and limited by the fact that it is created . . Therefore, saying that God is one is to say that God is indistinct from all things." 36

The term "one" signifies Existence Itself in itself along with the negation and exclusion of all non-being. Unity or the One most properly belongs to God, even more than the terms "the True" and "the Good." Quoting Macrobius, Eckhart contends that it not only means that God is one, but also that He is the only one:

The One which is called the Monad, that is, unity, is not a number, but the source and origin of all number. . . . Since it is one, it cannot be numbered itself; nevertheless, it creates innumerable kinds of genera from itself and contains them within itself. 37

This interchangeability of One and Existence explains a certain fluctuation in Eckhart's characterization of the inner ground of the Trinity. To this we now turn. Given the purpose of this article, I can only in a rather sketchy manner comment on the most characteristic topics such as the close connection between the intratrinitarian dynamics (more in particular the generation of the Son) and God's creative activity; the role of the redditio completa; and the participation of the soul as intellect in this return.

A.3. Bullitio and Ebullitio: Negative anthropology and the role of the intellect First however, we need to observe that Eckhart's trinitarian doctrine is not as elaborate nor as consistent as Ruusbroec's. For instance, two main patterns can be discerned in his trinitarian thought, one according to which the Godhead is identified with Esse, and the Father, Son, and Spirit with Unum, Verum, and Bonum; another, less predominant, attributes Unum

35. D. Turner's excellent study, The Darkness of God. Negativity in Christian Mysticism (Cambridge, Cambridge University Press, 1995), argues this point elegantly. Eckhart's assertions of indistinction are therefore innocuous enough; more problematic is his theory of analogy and in particular the connaturality of the human and divine intellect which grounds those assertions.

36. Comm.Wis. no. 144, McGinn II, p. 166.

37. Comm.Wis. no. 149, McGinn II, p. 168. Eckhart quotes from Macrobius's Commentary on the Dream of Scipio 1.6.7. 
to the Godhead and Esse to the Father. ${ }^{38}$ Whatever pattern prevails, the same spiritual dynamics apply, for both God's being and his oneness imply indistinction; just so, the soul has to become indistinguished and shun "every particular thing that reeks of distinction."39

Likewise, two patterns can be identified in the emanation of the Persons, one according to which the power of generating in the Godhead belongs more principally to the essence than to the relation that is Paternity, ${ }^{40}$ another one, more frequent, describes the Father as the principle of the divinity, out of which proceed the Son and the Spirit. ${ }^{41}$

The most remarkable feature of Eckhart's trinitarian doctrine is the close link between the generation of the Son and God's creative act: between bullitio - the dynamic life of the Trinity giving rise to the three divine Persons-and ebullitio or creation. The emanation of the Persons in the Godhead is the prior ground of creation. ${ }^{42}$ In his Commentary on Genesis this close relation between bullitio and ebullitio is clarified by a reference to Psalm 61:12:

the "beginning" in which "God created heaven and earth" is the first simple now of eternity. I say that it is the very same now in which God exists from eternity, in which also the emanation of divine Persons eternally is, was and will be. . . It is false to picture God as if he were waiting around for some future moment in which to create the world. In the one and the same time in which he was God and in which he begot his coeternal Son as God equal to himself in all things, he also created the world. "God speaks once and for all." (Job 22:14) He speaks in begetting the Son because the Son is the World; he speaks in creating creatures. . . . This is why it says ... : "God has spoken once and for all and I have heard two things." 43

Only occasionally Eckhart specifies obvious differences between bullitio and ebullitio: bullitio is not directed towards what is outside the producer, it does

38. McGinn I, p. 35. Although Esse and Unum are the terms most frequently predicated of the divine ground, Eckhart sometimes states that intellect preeminently belongs to the hidden Godhead, not only in the Par. Quest. but also in Sermon 9: "When we receive God in being, we receive him in his forecourt, for being is the forecourt of his dwelling. Where is He then in his temple, where He shines in holiness? Intellect is the temple of God" (W.II, p. 152).

39. Comm.Wis. no. 282, McGinn II, p. 172

40. Comm.Jn. no. 43, McGinn I p. 38 refers to ST I.41.5.

41. Par.Gen. no. 12. Another clear example is to be found in Sermon 15: "The Father is the beginning of the Godhead, for He comprehends himself in himself. From him comes forth the eternal Word, yet remaining within, and the Holy Ghost proceeds from both, yet remains within and the Father does not give birth to him, for $\mathrm{He}$ is the end of the Godhead, indwelling in it and in all creatures, and there is pure repose and a resting of all that ever obtained being" (W.II p. 53). The second pattern, more frequent according to B. McGinn, seems to qualify the traditional criticism of Eckhart's notion of a Godhead beyond the Persons.

42. Comm.Ex. no. 16, McGinn II, p. 46

43. Comm. Gen. no. 7, McGinn I, p.85. 
not proceed from something particular or from nothing, nor is it directed towards particular existence; in short, it does not produce effects. Further, what proceeds from what is one insofar as it is one, is always one, while what proceeds outside the One necessarily falls into plurality and division. ${ }^{44}$

Another distinctive feature of Eckhart's trinitarian thought and one of considerable importance for our purpose of comparing it with Ruusbroec's is the role the redditio completa (the return of the Intelligible Principle upon itself) occupies. This Neoplatonic principle taken from the Book of Causes (prop. 15), had been referred to by Aquinas when he treated of God's self-knowledge ( $S T$ I.14.2 ad 1). Thomas applies it to God who knows His essence (and all other things) directly through Himself, while the human intellect has to turn to phantasms to acquire knowledge (ST I. 84.7): it does not know itself by its essence but by its act ( $S T$ I.87.1). Eckhart uses it in a quite different context, not so much to explain God's (self-) knowledge, but to account for the "flowing back" of the Son into the Father: "The first outburst and the first effusion God runs out into is his fusion into the Son, who flows back into the Father." 45 Even more remarkable is that the soul as intellect can participate in this movement. This will be dealt with later, but one quotation will make Eckhart's application of the theme clear:

The Father bears his Son in eternity like himself. . . I say more: He has borne him in my soul. Not only is she with him and He equally with her, but He is in her: the Father gives birth to the Son in the soul in the very same way as He gives birth to him in eternity, and no differently. He must do it whether He likes it or not. The Father begets his Son unceasingly, and furthermore, I say, He begets me as his Son and the same Son, I say even more: not only does He beget me as his Son, but He begets me as himself and himself as me, and me as his being and his nature. ${ }^{46}$

This notion of redditio completa as used by Eckhart will be contrasted with the notion of regyratio, so central to the trinitarian doctrine of Ruusbroec. 47

Following the dynamic of Eckhart's thought itself we have progressed from a (brief) exposition of his trinitarian doctrine to the topic of the participation of the human intellect in the intratrinitarian life. This will be outlined in greater detail in the next section. First, I want to investigate the nature of the intellect (the "Spark") in greater detail, although it is impos-

44. Comm. Par.Gen. no. 9-12, McGinn I, p. 96-98

45. Sermon 35, W.I, p. 249. A more elaborate reference can be found in Comm. Ex. no. 16, 74.

46. Sermon 6, W.II, p. 134-35.

47. The notion of regyratio seems to have been anticipated by the beguine Hadewijch (c. 1210-1260), but the manner in which Ruusbroec develops it is highly original. 
sible to define it. The negative theology that pervades Eckhart's works is reflected in a negative anthropology that is closely connected with it. The ineffability of the divine ground results in a parallel ineffability of the "spark" of the soul which is one with it: "God, who has no name-He has no name-is ineffable, and the soul in her ground is also ineffable, as He is ineffable." 48 The spark is "uncreated," 49 neither 'this' nor 'that', "free of all names and avoid of all forms, entirely exempt and free, as God is exempt and free in himself." 50

The theme of the Spark is closely related to that of the Birth of the Son in the soul. B. McGinn explains:

Since the Father gives birth to the Son in eternity, and since there can be no temporal dimension in God, He is always giving birth to the Son; and since God's ground is one with the soul's ground, the eternal Father must always be giving birth to the Son within the ground of the soul. 51

When cataloguing the various passages where the Birth is discussed, one notices a certain inconsistency in terminology specifying the "place" where the Birth occurs, but it is clear that it is intimately connected with man's ability to know. ${ }^{2}$ In Sermon 2, for instance, Eckhart "situates" the Birth in the intellect, but above the powers of intellect and will is the "citadel" of the soul, in which even God cannot see inside unless He "leaves outside" all his divine names and personal properties. Just as the Godhead hovers beyond the Persons, so too the ground of the soul is beyond the powers. ${ }^{53}$ In other Sermons the birth takes place in the spark, but this presents us with the difficulty of the relation between intellect and the ground of the soul. Despite some minor inconsistencies, Eckhart's thought on this matter is rather clear: because of the connaturality of the divine ground and the essence of the soul, which is very much intellectual in nature, man can become deiform.

One of the most convincing texts in which the intellect is characterized as the main power that reaches into the divine ground is Sermon 69. According to this text, the intellect has five properties: it is detached from here and now; it is like nothing, just like God is like nothing; it is pure and uncompounded; it is ever inwardly seeking, allured by God's being that "ever abides in the innermost"; and finally, it is an image, indistinguishable from God's Image. 54 The intellect "bursts into the ground whence goodness and truth proceed, and seizes it in principio, in the beginning where goodness

48. Sermon 17, W.I, p. 172.

49. Sermon 13, W.I, p. 190.

50. Sermon 2, W.I, p. 76.

51. McGinn I, p. 51.

52. Tobin, Meister Eckhart, pp. 126-27.

53. Sermon 2, W.I, p. 71-78.

54. Sermon 69, W.I, p. 296-97. 
and truth are just coming out, before it has any name, before it burgeons forth." Whereas the will is satisfied with God as He is good, the "intellect strips all this off and enters in and breaks through to the roots, where the Son wells up and the Holy Ghost blossoms forth."55 In short, there can be no doubt about the privileged status of the intellect and the intellectual nature of the "spark." 56

\section{B. Meister Eckhart's Theology of the Image}

To clarify the foregoing outline we will now focus on the use of image in the writings of Eckhart. This allows us to recapitulate and illustrate much of the ground already covered and will also provide us with a point of departure from which we can compare the Meister's thought with that of Ruusbroec. We will also raise the crucial question whether Eckhart's view can be reconciled with a theology of grace. A brief consideration of Eckhart's spiritual goal, namely detachment, concludes this section.

One of the main differences between Eckhart's and Ruusbroec's theology is the way they interpret Genesis 1:26. Eckhart's tendency to draw a close parallel between the generation of the Son within the Trinity and God's creative act is especially noticeable in the case of man, who is created in God's Image. The language in which he describes the generation of the Son, the Father's Image, and the soul as image is often identical.

Eckhart's thought seems open to a radical and a more moderate interpretation, for at times he characterizes the soul as "made to the image," while at other times the soul itself $i$ the image of God. 57 These two positions do not have to exclude each other: it is not because the soul is created as an image of God that it therefore cannot be to the Image of God. Such a benign interpretation presupposes that one can distinguish between the soul as image and the Word as Image, but it is exactly this distinction that Eckhart rejects in his more radical Sermons. Ruusbroec, on the other hand, allows for a close union between our uncreated life in the Son (as divine idea) and our created life but he is careful to indicate that such a close union never becomes an ontological identity. For the same reason (union implies non-identity) Ruusbroec can give prominence to the role of grace in man's re-creation, while Eckhart's position on this issue is rather ambivalent as will become clear throughout this section. In what follows we will

55. Sermon 69, W.I, p. 297.

56. Sermon 76: "The soul has something in her, a spark of intellect, that never dies; and in this spark, as at the apex of the mind we place the 'image' of the soul" (W.I, p. 64).

57. For some examples of the soul as "imago Dei": Comm. Jn no. 84, McGinn I, p. 153; Par Gen. no. 140, McGinn I, p. 110; Benedictus 2, McGinn I, p. 243; Sermon 83, W.II, p. 332. "Ad imaginem": Comm.Jn no. 123, McGinn I, p. 170; Par.Gen. no. 138, 143, 154, McGinn I, p. 109, 112, 117; Comm. Wis. no. 283, McGinn II, p. 172. 
discuss some main passages from their writings without attempting to be exhaustive.

Sermon XLIX offers a good starting point to explore Eckhart's Imagetheology. In it he makes two introductory points: first, the image is to be found in the apex of the soul which is as we have noted earlier, intellectual in nature; second, he adds that "an image as such cannot be separated from that of which it is an image, even by the intellect." 58 How close Eckhart sees this union is hinted at in the next quotation, in which the perspective shifts from the generation of the Son to the manner in which the just man depends on Justice. After Eckhart has argued in a general way that first, an image has to be similar (one is similar to God when one is assimilated to no creature), more in particular in nature and species; that, third, equality belongs to the perfection of the image; fourth, that the image is the expression of its source; and, fifth, that everything that is alien or other is outside the notion of the image, he then continues:

From the fifth and second points above it follows that the image and its exemplar are not separately numbered as two substances, but the one is in the other. "I am in the Father, and the Father is in me." (Jn. 14:11) Furthermore, the just person depends on Justice formally, not like something from outside oneself, different and alien. This is the sixth property of the image. ${ }^{59}$

This immediate transition from the consubstantiality from the Father and Son to the connection between Justice and the just man illustrates Eckhart's tendency to identify both. Eckhart's emphasis on the connaturality of the divine and human intellect seems to suggest that he has more in mind than the mere idea that God and soul cannot be distinguished because of the transcendent nature of God in relation to His creation.

Moreover, man's return to its primal source is based on the "complete return" of the divine intellectual nature upon itself. This Neoplatonic principle, already referred to, underpins the re-creation of man who shares God's nature insofar as man is intellect:

Seventh, it is consequently necessary that the image be found only in intellectual nature where the same reality returns to itself in a "perfect return," and where the one that gives birth is one and the same with the child or offspring, finding oneself in the other and the other in oneself. 60

58. Sermon XLIX, no. 505, McGinn II, pp. 234-35.

59. Sermon XLIX, no. 510, McGinn II, p. 236.

60. Sermon XLIX, no. 510. 
This metaphysical principle throws light on some of Eckhart's most daring statements in the German Sermons.

In the Commentary on John, Eckhart again describes the "generation" of the just man in the same language as the generation of the Son from the Father. The just man, insofar as he is just shares the nature of justice univocally:

The just man proceeds from and is begotten by justice and by that very fact is distinguished from it. Nothing can beget itself. Nonetheless, the just man is not different in nature from justice, both because "just" signifies only justice, just as "white" signifies only the quality of whiteness, and because justice would make no one just if its nature changed from one place to another, just as whiteness does not make a man black or grammar make him musical. From this it is clear . . that the just man is the offspring and son of justice. One is called a son in that one becomes other in person, not other in nature. "The Father and I are one." (Jn. 10:30)—we are distinct in person, because nothing gives birth to itself; we are one in nature, because otherwise justice would not beget the just man, nor would the Father beget the Son who became other in person, nor would generation be univocal. . . If the Father and the Son, justice and the just man, are one and the same in nature, it follows . . . that the just man is equal to justice, not less than it, nor is the Son less than the Father. ${ }^{61}$

The nothingness of creatures is itself the foundation for this daring identification: "the just man or just thing in itself is dark and does not shine. It shines in justice itself, its principle, and justice shines in the just man." At the same time, Eckhart emphasizes that justice is not only in every just man, but also "entire outside every just man and thing." 62 All this seems to confirm our earlier interpretation: creatures are similar, if not identical to God insofar as their perfections are from him, and yet God is radically different from his creation.

Can we interpret Eckhart's statements concerning the birth of the Son in man, the image and the just man in the light of a theology of grace? This is the approach that E. H. Wéber puts forward in a stimulating article. ${ }^{63}$ Wéber argues that the whole of Eckhart's theology can only be properly understood as referring to the effects of the infusion of the uncreated gift of grace in

61. Comm.Jn. no.16-17, McGinn I, p. 127.

62. Comm.Jn. no. 22; See also no. 12: "The word, Logos or idea of things exist in such a way and so completely in each of them that it nevertheless exists entire outside each. It is entirely within and entirely without" (McGinn I p. 126). In what follows (no. 23-27), Eckhart elaborates on the theme of imago Dei to clarify further the dependence of the just man on justice, in a passage similar to that of Sermon XLIX.

63. E. H. Wéber, "La théologie de la grâce chez Maître Eckhart," Revue des sciences religieuses 70 (1996): 48-72. 
man. This seems an attractive option for it would allow us to situate Eckhart's often hyperbolic statements within an orthodox framework. However, Wéber (who mainly focuses on the Latin works) presupposes that it is meaningful to distinguish between man's created being and God's being-but it is just this distinction that Eckhart rejects in his most radical Sermons. If creatures are nothing, it is meaningful to state that for Eckhart everything is part of God's gracing activity; but it is equally meaningful to state that Eckhart does not have room for a distinct theology of grace.

Thus, not only does Eckhart often obscure the traditional distinction between the intratrinitarian processions (and more in particular the generation of the Son) or bullitio and God's creative activity or ebullitio, despite some occasional nuances; 64 more importantly, he also obfuscates the distinction between God's creative and re-creative activity. The point is not that he considers creation itself a grace-an orthodox enough point of view-but that God's gracing activity appears to become "naturalised." For example, in Sermon XXV (no. 262) grace is described as "a kind of boiling over" of the birth of the Son-exactly the sort of language that he uses elsewhere to describe creation (cf. Sermon XLIX no. 511). In several places Eckhart affirms the non-distinguishability of the divine ground and the soul's ground, of the birth within the Trinity and the birth within the soul. ${ }^{65}$ To see the latter as a metaphor for God's gracing activity is not unproblematic, for the former is a natural process "without the cooperation of the will, but rather with its concomitant activity." 66 The root of the problem seems to be, on the one hand, the close parallel between the generation of the Son within the Trinity and within the soul 67 and, on the other hand-but closely linked to it - the connaturality between God as intellect and man as intellect or, in more theological language, the fact that there is no distinction between the Son as Image of the Father and the image in man. 68 Again, statements of non-distinction are not problematic as such but rather the connaturality between God and soul on which they are founded. It is not without significance that Eckhart's Christology and above all his sacramen-

64. Comm. Par. Gen. 9-12; cf n.44 above.

65. Sermon 4: "The Father begets his Son in the eternal intellect, and thus the Father begets his Son in the soul just as He does in his own nature, and begets him in the soul as her own, and his being depends on his bringing his Son to birth in the soul, whether He would or no" (W.I, p. 285).

66. Sermon XLIX no. 511; also no. 512, McGinn II, p. 237. The fact that God is forced to pour himself into the detached man (Sermon 14) seems also at odds with the nature of grace.

67. Sermon Pf. 1: "And thus God the Father gives birth to his Son in the true unity of the divine nature. See, it is like this and in no other way that God the Father gives birth to the Son in the ground and essence of the soul, and thus unites himself with her" (W.I, p. 5).

68. Sermon 69: "Image and image are so fully one and joined that no difference can be discerned ... God in his omnipotence can understand no difference between them, for they are born together and die together.” (W.I, p. 298). 
tal theology can at the best only be qualified as underdeveloped. The soul's ground is one with God's ground and participates in the redditio completa of this intellectual nature upon itself. The unity of the divine ground with the soul's ground, the connaturality of the divine and human intellect, the supra-temporal act of creation and the close parallelism between the Birth of the Son from the Father within the Trinity and the Birth of the Son in man appears to reduce the relevance of the historical Incarnation and the role of grace in general.

Without wanting to minimize these difficulties, I would like to present a lenient interpretation of Eckhart's teaching on grace so as to avoid a simplistic contrast with the more balanced teaching of Ruusbroec. Although grace is sometimes characterized rather generally as everything we receive freely, undeserving though we be, Eckhart does occasionally distinguish between "grace freely given" (gratia gratis data) and "sanctifying grace" (gratia gratum faciens). ${ }^{69}$ However, he understands this traditional distinction in a manner which diverges from both Aquinas and Bonaventure since he identifies the first with the gift of creation and the second with the grace of salvation. ${ }^{70}$ Grace "freely given" is "common to all creatures," while "saving grace" is "proper only to intellective and good creatures." The following citation illustrates a close association between the theme of the Birth and grace although it also suggests they are not identical:

God's chief aim is giving birth. He is never content till He begets his Son in us. And the soul, too, is in no way content until the Son of God is born in her. And from that there springs forth grace. Grace is thereby infused. Grace does not work: its work is its becoming. It flows out of God's essence and flows into the essence of the soul and not into her powers. ${ }^{71}$

It seems that grace, infused by the Birth, is the medium that allows man to become one with the Son. Grace thus occupies only an intermediate position. In Sermon 70, after Eckhart has said that the light of the intellect is little compared to the light of grace, he states:

Yet the light of grace, great as it is, is little indeed compared with the divine light. . . As long as we are growing in grace, it is grace and it is

69. Comm.Wis. no. 272-73. Tobin Meister Eckhart, p. 107.

70. Sermon XXV no. 258, McGinn II, p. 218 and p. 222 n.16. In Brevil. V.2.2 gratia gratum faciens refers to grace that renders our actions meritorious; gratia gratis data however refers to the particular assistance which helps the soul prepare itself for receiving the gift of the Holy Spirit and not to the grace of creation. In ST I.II.111.1, Aquinas calls sanctifying grace the grace whereby man is united to God, while gratuitous grace refers to the grace whereby one man co-operates with another in leading him to God. Bonaventure is also familiar with this understanding of grace. See II Sent. d.27, a.1 q.1. ad 2.

71. Sermon 11, W.II, p.157. The idea that grace is bestowed upon the soul's essence and not in its powers was shared by Thomas, and later, by Ruusbroec. 
little, and in it we see God from afar. But when grace is perfected in the highest, it is not grace: it is a divine light in which one sees God. ${ }^{72}$

The mediating character of grace is also evident in the following quotation. Speaking of "something in the soul in which God is bare," he writes:

One master says that this thing is so present to God that it can never turn away from God and God is always present to it. I say that God has always been in it, eternally and uninterruptedly, and for man to be one with God in this requires no grace, for grace is a created thing, and no creature has any business there: for in the ground of divine being, where the three Persons are one being, she (= the soul) is one according to the ground..$^{73}$

Grace is thus the created means by which we receive the divine life, but it is not a share in the divine life itself. ${ }^{74}$ Because of the connaturality between God as intellect and the human intellect grace can only be a mediating factor:

The same knowing in which God knows himself is the knowing of every detached spirit, and no other. The soul takes her being immediately from God: therefore God is nearer to the soul than she is to herself, and therefore God is the ground of the soul with all his Godhead. 75

In short, Eckhart occasionally allocates an intermediary role to grace in man's deification; however, the connaturality between divine and human intellect is the true foundation of the union between God and man.

Furthermore, traditional teaching can sometimes be found in the Meister's works, for example in Sermon 46 in which Eckhart admonishes his listeners to abandon their particularity and to attain to their universal human nature which was transformed (überbildet) through the Incarnation of the Word. Here Eckhart notes that the eternal Word did not assume a particular human person, rather He assumed a free undivided bare human nature that was not yet particularized:

But since this very nature wherein you take yourselves has become the Son of the eternal Father by the assumption of the eternal Word, thus you, with Christ, become the Son of the eternal Father by reason of

72. Sermon 70, W.I, p. 289-90. In Sermon 21 Eckhart compares grace and beatitude to the blossom and the fruit.

73. Sermon 24, W.II, p. 313.

74. Cf. Tobin, Meister Eckhart, pp. 109-11. Tobin contrasts Eckhart's views with those of Aquinas.

75. Sermon 10, W.II, p. 139. 
taking yourselves by that same nature which has there become God. Beware therefore, lest you take yourselves as being either this man or that, but take yourselves according to your free, indivisible human nature. ${ }^{76}$

The Son took upon himself an indivisible, universal human nature "bare and without image," and hence the Father's Image became the image of human nature. This approach, reminiscent of the so-called theory of physical redemption is more attractive, if only because there is no necessary link with the "natural" generation of the Son within the Trinity and thus it allows room for grace: man can gradually uncover his nature redeemed in the historical Christ through grace and works. Moreover, Eckhart indicates in Sermon 1 (in contrast with other Sermons, for instance Sermon 6977) a difference between the Word as God's Image and the image as it exists in man: "each image as it radiates forth, existing by itself, is not the same in all respects as the Word. Rather, they have received the power to attain to likeness by the grace of the same Word." 78

A charitable interpretation could therefore run along the following lines: our intellect (the spark) is one with God and cannot be distinguished from God's intellect, although this does not imply that both are identical: our ground is identical with God's ground (inquantum principle), but not vice versa (asymmetric identity). Man has to actualize this divinity within through grace. The birth is both a natural datum, hidden from sinful man and the graceful necessary condition to achieve union with the Godhead. This explains why grace has only a provisional, intermediate character. ${ }^{79}$ The reader ought to decide whether such a benign interpretation suffices to solve the tensions and ambiguities in Eckhart's thought.

We have seen that Eckhart characterizes God as intellect, as being, or as nothing (when we attribute being to creatures). The outline of his spiritual ideal, detachment will vary accordingly. In one major German text, we find that detachment

draws a man into purity, and from purity into simplicity, and from simplicity into unchangeability, and these things produce an equality between God and the man; and the equality must come about in grace,

76. Sermon 46, W.II, pp. 27-28. Compare Sermon 67, W.II, p. 176.

77. See n.68 of this paper.

78. Sermon 1, W.I, p. 60.

79. In the Book Benedictus-Of the Nobleman, Eckhart is quite clear on the obstructive nature of sin that hides the divine image within: "He (= Origen) says that God's image, God's Son, is in the ground of the soul as a fount of living water (Jn. 4:14). But if anyone throws earth, which is earthly desire, on it, that impedes and conceals it, so that we do not perceive or grow aware of it; but the fount itself goes on living, and when they take the earth away that was thrown over it, then it appears, and we know that it is there." (McGinn I, p. 242; see also Comm. Jn. no.575, McGinn II, pp. 192-93). 
for it is grace that draws a man away from all temporal things, and makes him pure of all transient things. And you must know that to be empty of all created things is to be full of God, and to be full of created things is to be empty of God. ${ }^{80}$

If God is radically different from creation, man has to "let go" creatures, which is basically an abandonment of self. Just as God seeks nothing of his own but is free and empty in all his works, man who is one with God is perfectly free in all his deeds; he does them for love, without why. ${ }^{81}$ Creatures are a pure nothing and therefore man who seeks "something" along with God, actually finds "nothing." 82 Because God is above being, time, and place, man who has in his soul "a tiny drop of intellect, a little spark" can take God "bare, when He is stripped of goodness and being." 83 In short, the detached person is beyond temporality, place, multiplicity, particularity, and the like, and remains unmoved by happiness or sorrow. ${ }^{84}$ Detachment does not constitute the main spiritual ideal for the Prior of Groenendaal. To understand why this is we have to expound his trinitarian thought in some detail.

\section{RUUSBROEC}

Again, I will first give a broad outline before turning in more detail to Ruusbroec's theology of Image. I will explore the most dominant themes of Ruusbroec's trinitarian doctrine such as the primacy of the Father as principle of the Godhead, the fecundity of the divine nature, exemplarism, and the like, and I will point out the similarity to Bonaventure's trinitarian thought. I will also explore in some detail Ruusbroec's highly original theological contribution, namely the notion of regyratio and the role of the Spirit in it as an active principium diligendi. His distinctive approach will be constrasted with the view of Richard of St. Victor and Bonaventure. In the second section of Part II, I will argue that Ruusbroec's more traditional image-theology differs considerably from Eckhart's. Ruusbroec clearly distinguishes between the soul made "to the Image" and the Son as God's Image; between image and likeness; between God's creative and re-creative action; he also puts particular emphasis on the need for grace, made available in Christ and the sacraments, and the like.

80. On Detachment, McGinn I, p. 288.

81. Sermon 1, W.I, pp. 56-57.

82. Sermon 4, W.I, p. 284.

83. Sermon 9, W.I, pp. 152-53.

84. Sermon 10, W.II, p. 144. 


\section{A. The Trinitarian Doctrine of Ruusbroec}

The intratrinitarian life as outlined in the works of Ruusbroec can best be characterized as a circular movement, in which on the one hand, the Father out of his fruitful nature gives birth to his Son, from whose mutual contemplation the Spirit flows as a bond of love; and on the other hand, through the Spirit the divine Persons flow back into their shared being/essence. In the following passage, Ruusbroec outlines some of the main elements of his thought:

The noble nature [of God] which is the principal cause of all creatures, is fruitful; therefore it cannot remain in tranquillity in the unity of paternity because of the stirring (gherinen) of fruitfulness, but it has to give birth without cease to the eternal Wisdom, i.e. the Son of the Father. The Son is always being born, has been born, and remains unborn; yet it is one Son. Insofar as the Father contemplates the Son, the eternal Wisdom, and all things in the same Wisdom, He is born and is another Person than the Father. ... Where the nature is fruitful, the Son is in the Father and the Father in the Son; and where the Father gives birth to his Son, the Son is from the Father. And where the Father contemplates his Son, and all things in his Son, there He is born; and all this is one Son.

Neither from the fruitful nature (this is paternity), nor from the fact that the Father gives birth to his Son, does Love-this is the Holy Spirit-flow; but because of the fact that the Son is born as another Person, distinct from the Father, in which the Father sees him as born and all creatures in him and with him, as the life of all things; and because of the fact that the Son beholds the Father as fruitful and giving birth, and himself [the Son] and all things in the Father (this is a mutual beholding in the same fruitful nature): from this, Love, which is the Holy Spirit and a bond between the Father and the Son and between the Son and the Father, is brought about. With this Love the Persons are permeated and through it they embrace and flow back into the unity from which the Father is constantly giving birth. And when they have flown back into the unity, there is nevertheless no rest because of the fruitfulness of the nature. This giving birth and flowing back into unity is the work of the Trinity; thus there is threeness of Persons and oneness of nature. 85

I will attempt to expound the main thrust of Ruusbroec's trinitarian thought by trying to clarify this quotation. As a preliminary remark I would like to observe that three of its most important elements-namely, the primacy of the Person of the Father; exemplarism and, above all, the fecundity of the divine nature-are reminiscent of the trinitarian doctrine

85. Jan Van Ruusbroec. Werken I, Dat Rijcke der Ghelieven, pp. 1-100. ed. J. B. Poukens (Tielt: Lannoo, 1944), p. 60. Henceforth: Rg.I.60. 
of St Bonaventure. ${ }^{86}$ In this article I cannot fully expound this similarity, but I hope to provide sufficient evidence to support my contention that those interpretations which include Ruusbroec in the broader tradition of the "Rhineland Mystics," a theological and spiritual movement which finds its roots in the teaching of Albert the Great and other Dominicans of whom Meister Eckhart is the most noted, are in need of revision.

Indeed, according to Bonaventure, the fruitful nature is the primary principle in the generation of the Son. The divine nature is necessarily self-communicative (apparently a remote Pseudo-Dionysian legacy), while the model offered by Richard of St Victor will allow Bonaventure to move beyond this natural emanation to explain the procession of the Spirit as an emanation from a fecund will. While the divine nature is the primary principle in the generation of the Son, the will is a real principle in the spiration of the third Person. In short, two emanations can be distinguished: one per modum naturae (the fecunditas naturalis of the Father is the "cause" of the communication of the divine nature through generation) and another per modum amoris (the fecunditas voluntatis in the Father and the Son causes the procession of the Spirit).

The reader will have observed that in the quotation given above, Ruusbroec identifies "paternity" with the fruitful nature. This may appear strange (one would have expected that he would have reserved this term for the Father-Son relation), but it illustrates that Ruusbroec firmly locates the fruitful nature in the Father as origin of the Trinity. Indeed, the Father is "the principle of the whole Godhead with respect to being and Persons," 87 "the eternal beginning of the Holy Trinity." 88 Ruusbroec identifies the unity of the divine nature with the Father "because of the fruitfulness and the origin of its eternal works." 89 It also seems to indicate, although Ruusbroec

86. Cf. G. Emery: "Ces traits majeurs de la pensée bonaventurienne . . p peuvent être ramenés à trois idées fondamentales: la diffusion du souverain bien, la fécondité divine qui s'enracine dans la fontalité du Père (primauté, plénitude fontale), et l'exemplarité du Fils et du Saint-Esprit à l'égard des créatures" (p. 244). "C'est également dans ces intuitions fondamentales (fécondité et primauté, exemplarité), davantage que par tel autre aspect particulier de son enseignement, que Bonaventure se distingue d'Albert" (p. 245). (From G. Emery, La Trinité créatrice. Trinité et création dans les commentaires aux Sentences de Thomas d'Aquin et de ses précurseurs Albert le Grand et Bonaventure [Paris: Librairie Philosophique J. Vrin, 1995]).

87. Jan Van Ruusbroec. Die Geestelike Brulocht. Opera Omnia, iii, Corpus Christianorum. Continuatio Mediaevalis (CCCM) ciii, Lannoo, Tielt, ed. J. Alaerts, English trans. H. Rolfson. I will refer to this as Br., followed by the relevant book (a, b, or c) and lines: Br. b 2067. An excellent translation of some of Ruusbroec's main works, including Brulocht and Spieghel, is to be found in John Ruusbroec: The Spiritual Espousals and other works, Classics of Western Spirituality, intro. and trans J. A. Wiseman, pref. L. Dupré, (Paulist Press, 1985). Henceforth, Wiseman.

88. Jan Van Ruusbroec. Werken II, Van den gheesteliken tabernakel, edited by P. Stracke, 1948, Lannoo, Tielt, p. 1-365; p. 151. Henceforth: T.II.151

89. T.II.34. Elsewhere, Jan Van Ruusbroec, Werken III, Een Spieghel der Eeuwigher Salicheit, edited by L. Reypens, (Tielt: Lannoo, 1947.) p. 129-219; p. 167. Hence- 
does not deal with this problem in a systematic manner, that the Persons are primarily constituted per originem and not per relationes: the Father is unoriginated and fruitful source of the other Persons; the Son is from the Father, and from their mutual contemplation proceeds the Spirit. What Z. Hayes writes about the position of the Father in Bonaventure's thought also applies to Ruusbroec, who, as we have seen, occasionally identifies paternity and fruitful nature:

logically prior to His full and actual paternity which is the active relation to the Son that constitutes Him as Father in the full sense, He is Father already in an inchoative sense in as far as His personal property of being fecund source of all others has a logical priority to any actual emanations. ${ }^{90}$

This position has the advantage that it is not faced with the problem that, if the Persons are constituted by relations, and if relation arises from procession, the first procession logically presupposes a Person who actively generates (which implies that the first Person is prior to the relation by which He is said to be constituted). ${ }^{91}$

What distinguishes Bonaventure's understanding of the generation of the Son from that of Thomas Aquinas or Augustine, is his emphasis on natural emanation (in this context adopting the Neoplatonic notion of bonum diffusivum). This does not mean that the intellect is not involved, but intellect precisely as intellect is not fecund; it is so only in as far as it springs from the fecund nature of God. Out of inner necessity the Son flows from the divine nature as a perfect self-expression of the Father; therefore He is called the Word or Image. ${ }^{92}$

Likewise, Ruusbroec writes that the Father, as "a beginning without beginning" has "perfectly comprehended himself in the ground of his

forth: Sp.III.167 we read: "Nature is fruitful, paternity and Father." Seeing that the divine nature can only conceptually be distinguished from the divine essence/being in which the Persons flow back, Ruusbroec has no room for a Godhead "beyond" the three Persons, a view that is traditionally attributed to Meister Eckhart.

90. Z. Hayes, "Introduction" to Saint Bonaventure's Disputed Questions on the Mystery of the Trinity, intro. and trans. Z. Hayes (New York: The Franciscan Institute, 1979), p. 39.

91. Hayes, Saint Bonaventure's Disputed Questions p. 38. Of course, the contrast between the two approaches (distinction of the Persons by origin or by relations) is not absolute but rather a matter of emphasis. Bonaventure calls the Persons subsistent relations, and in one place Ruusbroec writes that "the relations which constitute the personal properties exist in an eternal distinction." (Br.b1069-71) Bonaventure also argues that the personal property of the Father is paternity, not innascibility (I Sent. d.28 q.3): while innascibility is logically prior and lies at the root of the personal character of the Father, it is in paternity that He finds the fulness of his personal reality. See also, Hayes, p. 43

92. Hayes, Saint Bonaventure's Disputed Questions, p. 45. 
fruitfulness" so that the Son has gone out as another Person in the Godhead, and "through this eternal birth all creatures have gone out eternally, before they were created in time." 93 The Son reveals the Father, although his nature remains always within the Father. ${ }^{94}$ Therefore, He is called the Wisdom of God, ${ }^{95}$ his Clarity, ${ }^{96}$ Light, ${ }^{97}$ Image, and so on. I will expound the latter attribute in greater detail in the following section.

The Spirit is seen as the Love between Father and Son, proceeding from their mutual contemplation. He is their "bond of love." This language recalls that of Richard of St. Victor who as already indicated, exerted a considerable influence on Bonaventure. 98

A brief outline of their key positions will help to elucidate Ruusbroec's position wherein the most striking element seems to be the role he attributes to the Spirit as an active principle of regyratio.

Richard argued from an analysis of the divine essence as love to the existence of the Trinity. When two love each other mutually there is love on both sides (dilectio), but there is no shared love (condilectio). Shared love is properly said to exist when a third person is loved by two Persons harmoniously and in community and the affection of the two Persons is fused into one affection by the flame of love for the third. ${ }^{99}$ This condilectio is defined as nothing other than "the mutual coming together of intimate benevolence and supreme harmony" (nisi intimae benevolentiae et summae concordiae mutua concursio). 100 Richard discerns three modalities of love within the Trinity: amor gratuitus, found in the Father who gives without having received; amor debitus, in the Spirit who receives all love without returning it; and amor ex utroque permixtus, found in the Son, whose personal property it

93. Br.c, 130-32.

94. Jan Van Ruusbroec. Werken IV Vanden XII Beghinen, ed. J. Van Mierlo, Tielt: Lannoo, 1948, p. 1-224, p. 63. Henceforth: 12B.IV.63.

95. Rg.I.73.

96. Br.b 240.

97. T.II.33.

98. Although Augustine never developed the analogy of mutual love between human persons, there are traces in his works that hint at the idea that Richard was to exploit, as Gonzalez has shown (e.g. De Trin. VI.§7, where it is said that the Holy Spirit is "something common to Father and Son, whatever it is, or is their very commonness or communion, consubstantial and coeternal. Call this friendship, if it helps, but a better word for it is charity." Further: "Non amplius quam tria sunt, unus diligens eum qui de illo est, unus diligens eum de quo est, et ipsa dilectio": "And therefore there are not more than three; one loving him who is from him, and one loving him from whom he is, and love itself" [transl. E. Hill, Saint Augustine: The Trinity (New York: New City Press, 1991], p. 209-10). In De Trin. VIII.14 we find: "Ecce tria sunt: amans et quod amatur et amor."

99. De Trin. III.19; trans. from: Richard of St. Victor: The Twelve Patriarchs, The Mystical Ark, Book Three of the Trinity, trans. G. A. Zinn, pref. J. Chatillon, Classics of Western Spirituality (New York: Paulist Press, 1979), p. 392.

100. De Trin. III.19 Latin text and French translation in G. Salet, Richard de St Victoire, La Trinité. Sources Chrétiennes (S.C.) no.63 (Paris, 1969), p. 210 
is to proceed from another and to have a Person that proceeds from him. ${ }^{101}$ (Of course, the Spirit can bestow amor gratuitus on a created person, but obviously not in its in fullness, for it would not be appropriate to love in such a degree that which is not worthy of this full love.) ${ }^{102}$ Because Richard identifies these modalities of love with each of the three Persons, ${ }^{103}$ the Spirit from whom nobody proceeds cannot share his love actively with another Person. What, asks Richard, could the Spirit, to whom the fullness of divine love has been communicated, return of the love He received?104

It is here that Ruusbroec parts ways with Richard (and Bonaventure), for according to him, the Spirit is an active principle by which the divine Persons flow back into their shared unity or essence. For Ruusbroec, it pertains to the essence of love to return what it has received in order to allow the other to give once again, and so forth: do ut des.

This notion of the Spirit as an active principle of the regyratio is quite unique to Ruusbroec, and it has bearings throughout his doctrine, for instance on his understanding of the relation between God and man, the Incarnation, Passion and Eucharist, the gifts of the Spirit, and the like, which have to be interpreted in the light of the bestowal of gifts by God in order to establish a loving relationship with man in which he can reciprocate these gifts in a dynamic that finds its origin in the heart of the Trinity. Thus, the Spirit is not just the "passive" Love, resulting from the mutual contemplation of Father and Son, but it is an active principle in their flowing back, so that the trinitarian life can be described as a circular movement or even a whirlpool, an image especially dear to Ruusbroec. ${ }^{105}$

101. De Trin. V. 19 , S.C. p. 350

102. De Trin. V.18, S.C., p. 348.

103. Oportet itaque absque dubio ut in summa simplicitate idem ipsum sit esse quod diligere. Erit ergo unicuique trium idem ipsum persona sua quod dilectio sua ... Quoniam ergo quaelibet persona, ut diximus, est idem quod amor suus et assignata singularum discretio constat in solis jam dictis tribus, sicut quartam proprietatem sic quartam personam nullatenus ibi invenire poterimus (De Trin. V.20, S.C. p. 352). As this quotation makes clear, Richard uses this reasoning to argue against the thesis (attributed to and duly retracted by Gilbert of Poitiers) that there is a "fourth entity" in the divinity.

104. De Trin. V. 18, S.C. p. 348: "Quid itaque indebiti amoris possit eis rependere, a quibus constat eam omnem plenitudinem gratis accepisse? Et quoniam proprium est ipsius ... de se procedentem non habere, non est in divinitate cui possit plenitudinem gratuiti amoris exhibere."

105. Ruusbroec does not use the term regyratio-the return of the Persons into their shared unity-as he wrote in Middle-Dutch. However, he translates it, quite accurately, as wederboeghen, used as verb or substantively as in the following passage: "Daer es de vader, met den sone ende alle die gheminde, bevaen ende behelst in bande van minnen, dat es, in enecheit des heilechs geests. Ende dit es die selve enecheit die vrochtbaer es na den utebroeke der persone, ende in den wederboghene i ewech bant der minnen die nemmermeer onbonden en wert" (Jan Van Ruusbroec, Boecsken der Verclaringhe. Opera Omnia, i, CCCM ci, [Tielt: Lannoo, 1981] ed. G. De Baere, English trans. Ph. Crowley and H. Rolfson. Henceforth, Boecksken 
Does this mean that Ruusbroec teaches that the Spirit is the originating principle of the Love between Father and Son? The notion of the Spirit as principium diligendi was rejected by both Aquinas and Bonaventure, and it is illuminating to investigate the latter's position to understand Ruusbroec's teaching, which does not deal with the problem explicity. ${ }^{106}$

In a passage not dissimilar to the extract from Ruusbroec quoted at the beginning of Part II, Bonaventure writes:

Amor qui est Spiritus Sanctus non procedit a Patre in quantum amat se nec a Filio in quantum amat se, sed in quantum unus amat alterum, quia nexus est: ergo Spiritus Sanctus est amor, quo amans tendit in alium: ergo est amor et ab alio et in alium et ista duo complectuntur rationem processionis perfectae. ${ }^{107}$

Bonaventure rejects the notion that the Spirit is a bond in the active sense as though He joined Father and Son; rather it ought to be understood in the passive sense, namely in the sense that He proceeds from each of them. There are therefore three ways to understand love: essential (when it refers to the divine essence, for example, that love whereby God loves himself or creatures, or whereby one of the divine Persons loves the others), notional (this is the love by which the procession of the third Person becomes known) and personal (the Spirit is the end of a perfectly liberal act of the will found in Father and Son). 108

From this we can conclude that calling the Spirit the bond of love does not necessarily mean that $\mathrm{He}$ is the originating principle by which the Father and Son love each other; on the contrary, the Spirit proceeds from their mutual relation; He does not constitute it. Having said that, "once" the three Persons have been constituted, Ruusbroec (as distinguished from Bonaventure) does attribute a special role to the Spirit as an active principle of regyratio. In

followed by the relevant lines in the Middle-Dutch text: Boecksken, 378-83). A translation by Surius (1552) of this passage, also to be found in the critical edition (CCCM, p. 140), runs as follows: "Ibi Pater cum Filio, et cum eis electi omnes circumplectuntur vinculo charitatis, in divina unitate: quae quidem secundum personarum emanationem foecunda est, in earum autem reflexione sempiternus ac insolubilis est nexus amoris." Surius is sensitive to both the Neoplatonic (emanatio, reflexio) and the Richardian (nexus amoris, vinculum charitatis) vocabulary Ruusbroec uses. This vocabulary, especially when applied to describe the intra-trinitarian dynamics in its out-going and in-going aspects (descibed in terms of "flowing in" or "flowing out") betrays a distinct Pseudo-Dionysian influence-in which Augustinian elements are then subsumed-similar again to Bonaventure's approach. See also the quotation at the beginning of Part II.

106. ST I.37.2 and I Sent.d.10; d.32.

107. I Sent.d.13 q.1.

108. L. Mathieu, "Introduction" to Breviloquium, partie 1. La Trinité de Dieu (Paris: Editions Franciscaines, 1967), p. 32: Hayes, St. Bonaventure's Disputed Questions, p. 60. 
Ruusbroec's view, the Spirit who, to put it in Richardian language, receives the fullness of love from the other two Persons, returns what He has received to the other Persons of the Trinity; likewise the Spirit will give Himself to man (Ruusbroec deals at length with the gifts of the Spirit throughout his works), but will demand back from man whatever He has given.

After this brief outline of Ruusbroec's trintarian doctrine, it is time to examine his theology of the Image. In expounding it, the contrast with Eckhart will become evident.

\section{B. Ruusbroec's Theology of the Image}

Ruusbroec gives a relatively radical yet balanced interpretation of traditional exemplarism. We have an eternal life, before we were created in time, in God's Wisdom. When the almighty Father has perfectly comprehended Himself in the ground of His fruitfulness, the Son, the eternal Word of the Father, has gone out as a second Person in the Godhead. Through this eternal birth all creatures have gone out from all eternity, before they were created in time. God the Father has known the creatures in the Son, as life-giving ideas. ${ }^{109}$ In the Son, the divine Image, all creatures have an eternal life "without themselves." He is the "exemplar of all creatures."110

On the one hand, Ruusbroec stresses the strict unity between and dependence of our created life on our eternal life in God's Image as divine idea. Our eternal life in God's Image is characterized as the supra-being (overwesen) of our created being. 111 Each soul is created as a living mirror, on which God has impressed the image of his nature.

In this way He lives imaged forth in us and we in him, for our created life is one, without intermediary, with this image and life which we have eternally in God. That life which we have in God is one in God, without intermediary, for it lives in the Father with the unbegotten Son and is begotten with the Son from the Father, flowing forth from them both with the Holy Spirit. We thus live eternally in God and He in us, for our created being lives in our eternal image which we have in the Son of God. This eternal image is one with God's wisdom and lives in our created being. 112

On the other hand, Ruusbroec stresses that, although our created being and life are directly dependent on this image as on their eternal cause, our created being does not become God, nor does God's Image become a creature, "for we are created to the image, that is created so as to receive

109. Br.c 132-33.

110. Br.b 1050.

111. Sp.III.167.

112. Sp.III.202, Wiseman, p. 237. 
the image of God, and that image is uncreated and eternal Son of God."113 In short, Ruusbroec clearly distinguishes between our life in the Image (as divine idea, only conceptually distinguishable from the Son) 114 and our created life to the Image. The Image refers primarily to the Son who can also be called the image of the Trinity because He mirrors the Father, the principle of the whole Trinity. The soul can only be called image in a derivative sense. 115

To clarify his teaching on the union between the Word and the soul, Ruusbroec uses the metaphor of the mirror:

This image, which is the Son of God, is therefore eternal, prior to all creation. It is to this eternal image that we have been made, for in the most noble part of our soul-namely in the ground of our higher powers - we have been created as a living and eternal mirror of God, on which God has impressed his eternal image and on which no other image can ever be impressed. This mirror remains constantly before the face of God and therefore participates in the eternity of the image which it has received. In this image God knew us in himself (in hemselven) before we were created, and now that we have been created in time he knows us in this image as destined for himself (toe hem-selven). This image exists essentially and personally in all persons. ${ }^{116}$

According to medieval physics the reflected image in the mirror (of man's soul) is not just an optical illusion but it has ontological significance: it is real. In this case, it is the "place" where God's eternal, creative activity and our temporal createdness meet. Therefore Ruusbroec can say that this mirror of the soul becomes "eternalized" through the image that it has received or that it is "beyond time and place." 117 God and soul become indistinguishable (the soul becomes the Brightness it receives) but they are not ontologically identical. 118

Indeed, Ruusbroec's language seems at times similar to that of Eckhart, especially when he links the generation of the Son to the birth of the Son in the soul; 119 there can be no doubt that "the very image of God which we

113. Sp.III.166-67, Wiseman, p.213.

114. Br.c 143.

115. Sp.III.204-5: "Even though God's Image is in the mirror of our soul and is united with it without intermediary, still the image is not the mirror, for God does not become a creature. The union of the image in the mirror is, however, so great and so noble that the soul is called the image of God." (Wiseman p. 239)

116. Sp.III.116, Wiseman p. 213

117. Br.b 1661.

118. Br.c 76-77.

119. For instance in Sp.III.167: "It [the topmost of our soul] is therefore an eternal and living mirror of God which ceaselessly receives the eternal birth of the Son, who is the image of the Holy Trinity" (Wiseman, p. 214). See also Book III of Die Geestelike Brulocht (The Spiritual Espousals). 
have received and which we bear in our soul is the son of God," but significantly he adds: "Nevertheless we are not God's Wisdom, for in that case we would have created ourselves, which is impossible and contrary to faith, for all that we are and have comes from God and not from ourselves." 120

The main difference between Ruusbroec and Eckhart in this respect seems to be that according to the latter's more audacious statements the soul of man himself is (indistinguishable from) the Image of God (a position argued on the basis of the connaturality of the divine and human ground, intellectual in nature and sometimes qualified by what I called asymmetric identity), while according to the former the Son is the Image, ontologically clearly distinct from the soul in which He is received.121 This is an important nuance. Eckhart used the metaphor of the image (in a general sense) to argue for the connaturality and equality of the image and the object it images forth; when he applies this to the soul, the distinction between the Word and the soul as image appears to become problematic indeed. ${ }^{122}$ Ruusbroec emphasizes the close union of Word and soul, but his metaphor of the mirror allows him to draw a clear distinction between the (created) mirror of the soul and the divine Image it reflects. Ruusbroec is careful to stress that, although we have an eternal life in God, "we are not God, nor did we make ourselves. We also did not flow forth from God by nature, rather since God knew and willed us eternally in himself, He created us not by nature or out of necessity, but out of the freedom of his will."123 We are only like God which entails a radical otherness from God that will never be transcended:

We are one life in God in our eternal Image above our createdness. . . . Yet we remain other than God and cannot become one, and have to remain eternally in otherness, each one in his own individuality. In this regard God has made us (only) like himself in bare nature, according to our higher faculties. ${ }^{124}$

Even though we are one with God, we must remain forever other than God. 125

Although the soul cannot be called the image of God, or only in a secondary sense, it receives from its being ad imaginem three properties that

120. Sp.III.205, Wiseman, p. 239.

121. See for instance Sermon 16b: "God is here in the image without means, and the image is without means in God. But God is in far nobler fashion in the image than the image is in God" (W.I. p.125).

122. Cf. Sermon 16b.

123. Sp.III.201, Wiseman, p. 237.

124. 12B.IV.30.

125. Jan Van Ruusbroec. Vanden Blinkenden Steen Opera Omnia, x,. ed. G. De Baere, Th. Mertens, and H. Noë, intro. Th. Mertens and P. Mommaers, English trans. A. Lefevere, (Tielt: Lannoo 1991). Henceforth, St., followed by the relevant lines: St.642-44. 
are but one in nature. The first is an essential bareness devoid of images. Through it we are like the Father and become united with Him and His divine nature. The second is called the higher reason of the soul in which we receive the Son and become one with him. The third is the "spark of the soul" (de vonke der zielen) which is the soul's natural tendency toward its source. Through this, we are like the Spirit, and through receiving Him we become one spirit and love with God. 126

Several interesting observations can be made: The ad imaginem (toe den Beelde) entails a fundamental dynamic of the soul toward the divine; therefore Ruusbroec implicitly rejects the (static) view that the three faculties man "possesses" reflect the divine Image; this more dynamic view is also more congruent with his dynamic view on the inner life of the Trinity. Second, the spark of the soul is more akin to the volitive power than to the intellectual power, in contrast to the majority of Eckhart's texts. Third, and again in contrast to Eckhart, Ruusbroec pays considerable attention to the memory as ground of the soul in the traditional Augustinian sense.

\section{The Need for Grace: Redemption in Christ}

Furthermore, not only does Ruusbroec differ in his understanding of the "image" of the soul, he also puts considerable emphasis on the fact that we are made to the likeness of God. This traditional distinction between image and likeness finds only a marginal place in Eckhart's thought, if any at all. The distinction has remote Augustinian roots but the way Ruusbroec develops it seems, again, more indebted to Bonaventure. ${ }^{127}$ All creatures are vestiges of God; only man is made to the Image, while likeness refers to deification by the gifts of the Spirit. ${ }^{128}$ Similarly, Ruusbroec associates likeness always with the gift of God's grace and our virtuous behavior in response to it, while image has a more ontological, 'natural' connotation. The Image is the Word himself, or his reflection in the mirror of the soul. The likeness refers to God's gifts. The image presupposes oneness, the likeness difference; it is on the mediated, active level. Ruusbroec explains:

126. Sp.III.167-68, Wiseman, p. 214.

127. E. H. Wéber: "Il s'agit de l'ordre de la grâce, alors que le thème de l'image de Dieu se réfère principalement à une structure de nature. Impliquant relation avec Dieu comme objet d'opération aimante, les vertus théologales sont ici l'élément essentiel. Par elles l'âme est réstituée à sa perfection première. . . . Il ne s'agit plus de la façon de voir augustinienne, mais d'une conception qui est issue d'une autre source. La doctrine bonaventurienne de la ressemblance de l'âme avec Dieu s'enracine chez de nombreux auteurs du XIIe s. et dans les Distinctiones d'Alain de Lille qui rattachent la fonction d'imago Dei aux principes qui constituent la nature de l'âme et celle de similitudo Dei aux dons gratuits de la restauration" (E. H. Wéber Dialogue et Dissensions entre St Bonaventure et St Thomas d'Aquin à Paris (1252-1273) Paris: Librairie Philosophique J. Vrin, 1974, pp. 93-94).

128. Breviloquium, II. 12. 
For since we are made to the likeness of God, that is, to the grace of God-for it is a deiform light which shines through us and makes us like (Him), and without this light which makes us like (God), we cannot attain union supernaturally-although we cannot lose the image nor the natural unity with God (die natuerlijcke eenicheit met Gode), if we lose the likeness, that is, the grace of God, then we are damned. ${ }^{129}$

The "natural" character of the image (as distinguished from likeness) explains the possibility of natural mysticism:

Because it [the eternal life] is in all of us by nature, some persons are able to perceive it apart from grace, faith and the practice of virtue. These are persons who have idly turned inward, above and beyond perceptible images, to the bare simplicity of their being. There they think they are holy and blessed, and some even think they are God.

This "living life" is in all of us essentially, in our bare nature, "for it is above hope and faith, above grace and all virtuous exercises." 130 Yet on the very next page we read that, although it is natural to all rational creatures,

no one can perceive, find or possess this life unless through love and God's grace he has died to himself in the living life, been baptised in the spring, and been born again of God's Spirit in divine freedom. He will then always remain dwelling in God, united with him in the living life and, through the richness and fullness of his love, will always be renewed and flow out with God's grace in every virtue. ${ }^{131}$

What Ruusbroec appears to be saying is that the Image of God in us provides a necessary and natural condition for our participation in the trinitarian life, but it needs to be actualized through grace. Without grace, man can enjoy the natural image in himself, but this is a futile and self-centred activity, alien to the true Christian life.

Ruusbroec is deeply aware of the fallen nature of man. Sin puts a "screen" between the essential unity of our mind (in which God dwells) and the faculties which can only be overcome by God's grace, that is, in likeness:

And therefore, the sinners and the damned spirits are in darkness, because they lack the grace of God which would enlighten and lead and instruct them to that enjoyable unity. Yet, the essential unity of the spirit is so noble that it cannot choose to be annihilated; but sin constitutes

129. Br.b 1683-89. Although this quotation seems to suggest that Ruusbroec identifies grace and likeness, his more considerate teaching is that likeness (or similitudo) is attained by grace, that is, likeness refers to man's deiformity which is acquired by means of faith, hope and love.

130. Sp.III.199, Wiseman, p. 235.

131. Sp.III.200, Wiseman, p. 236. 
such a great obstruction and darkness and unlikeness between faculties and being-in which God lives- that the spirit cannot achieve union with its own being, which would be its own (domain) and its eternal resting place, were it not for sin. For whoever lives without sin lives in likeness and in grace, and God is his own (domain). And thus there is need for grace. ${ }^{132}$

Grace is absolutely necessary for deification-in each of his major works Ruusbroec gives an extensive treatment of the seven gifts of the Holy Spirit-but for him too grace seems to have only an intermediate function: through it we come to participate in the Father's Image and share the intratrinitarian life which is beyond grace.

Grace has above all become available in Christ. Unlike Eckhart, Ruusbroec has a sophisticated and comprehensive Christology. In this article I cannot do justice to this important aspect of his theology; however, an elaborate treatment would be a needless exercise for on this issue there are not sufficient elements available to make a relevant comparison between Ruusbroec's thought and that of Eckhart: apart from some general and scattered remarks, Eckhart has very little to say on the role of the historical Christ in our redemption. Christ's Passion and his self-gift in the Eucharist hardly figure in his writings. 133 This different emphasis is evident from Ruusbroec's very first work, The Realm of Lovers, probably written in the early 1330s. ${ }^{134}$ The book has a highly complicated structure, built around an intricate interconnection of the seven gifts of the Spirit, the beatitudes, the angelic hierarchy, the hierarchy of man's lower and higher faculties and, not least, a growing likeness to the Person of Christ, both in his human and divine nature. (This emphasis on the humanity and life of Christ, again Franciscan in origin, was to exert a considerable influence on the Devotio Moderna.)

Creation in God's Image and likeness is only the first of four signs of love God has shown us. ${ }^{135}$ The second is the Incarnation (an illustration of the humble nature of God, according to Ruusbroec). Here Ruusbroec's speculative bias is illustrated by his recuperation of the so-called theory of physical redemption, which we have encountered in the more traditional writings of Eckhart as well. The third is the Passion. Here it is worthwhile to observe that Ruusbroec considerably qualifies Anselm's theory of satisfaction in the light of his analysis of the reciprocal nature of love. The Cross is the most sublime sign and cause of the restoration of the reciprocal love between God and man, a love that needs to be mutual because it mirrors

132. Br.b 1735-45.

133. There are some exceptions, although the statement generally holds true. See for example Sermon XLV no. 464-68 in which Eckhart spells out how one ought to carry Christ's Cross (McGinn II, p.231-33).

134. J. Wiseman, "Introduction" to John Ruusbroec: The Spiritual Espousals and other works, p. 7.

135. For the four signs of love, see Sp.III.165-72, Wiseman, p. 212-17. 
the trinitarian life in its dual aspect of movement and stillness, threeness and oneness, "flowing forth" and "drawing in," "generosity" and "avidity." Only the God-man, the sinless Mediator between God and humanity, could re-establish this reciprocity; God's selfgift in the Cross enables us to return his gift. The close link with the Eucharist, the fourth sign of love in which we receive in order to give, "in which we eat and are being eaten" is clear. ${ }^{136}$ Christ opens the door to the intratrinitarian life: He transforms our sensual life (through the gift of his bodily life, both in the Eucharist and in his exemplary life), our higher faculties (through the gift of his spirit), and our personality ${ }^{137}$ (through the gift of his personality, whereby we are capable of "transcending ourselves and the createdness of Christ and rest in our inheritance, that is, the divine essence, in eternity"). 138

This divine essence should not be understood in an Eckhartian sense. As will have become clear by now, Ruusbroec puts the mystery of the Trinity at the heart of his doctrine in noticeable contrast with Eckhart, who wanted to penetrate into the Godhead beyond the Trinity. Their concepts of the mature Christian life will differ accordingly. For Eckhart, this goal is detachment, based on the connaturality of the divine and human intellect:

Therefore I say, if a man turns away from self and from all created things, then-to the extent that you do this-you will attain to oneness and blessedness in your soul's spark, which time and place never touched. This spark is opposed to all creatures: it wants nothing but God, naked, just as He is. It is not satisfied with the Father or the Son or the Holy Ghost, or all three Persons so far as they preserve their several properties. . . . it wants to get into its simple ground, into the silent desert into which no distinction ever peeped, of Father, Son or Holy Ghost. 139

Ruusbroec's spiritual goal is the Common Life (een ghemeyn leven), modeled after the dynamic of the trinitarian life itself, based on a radical interpretation of the traditional doctrine of exemplarism. In the life of the "common" man activity and rest or contemplation are perfectly integrated in an exact reflection of the intratrinitarian dynamics in its out-going in-going and enjoyable or essential moments:

God's Spirit drives us ["breathes us out"] towards loving and virtuous activity, and He draws us back in to rest and enjoy ... Therefore, to go in in idle enjoyment, and to go out in virtuous activity, and to remain constantly united with God's Spirit: this is what I mean. ${ }^{140}$

136. Rg.I.52; Sp.III.158.

137. Br.b 1337-6.

138. Br.b 1394-97.

139. Sermon 48, W.II. p. 105.

140. Jan Van Ruusbroec, Werken III, Van VII Trappen, pp. 221-72, ed. L. Reypens (Tielt: Lannoo, 1947), p.269. 
In an almost untranslatable passage Ruusbroec summarizes this ideal of the "common" man (een ghemeyn mensche):

on the one hand the mind (ghedachte) is turned to all virtues, so that it perfectly resembles the fruitful nature of God, which incessantly flows out according to the Persons with every gift to meet the need of creatures; at the same time this man's mind will remain essentially suspended (weselijc inhanghende), so that he is being transformed in the fathomless clarity just like the divine Persons sink away every moment in their fathomless being/essence (wesen), and overflow (there) in enjoyment; yet they are eternally outflowing and active according to Personhood in the fruitful nature. . . The noble, "common" man ... flows out with every virtue and he is similar to God who flows out with all his gifts; and he remains within in eternal enjoyment with God above all gifts. ${ }^{141}$

\section{CONCLUSION}

In my view, an accurate comparison of two authors who seem to share a common terminology requires that one takes into account the larger context of their thought rather than merely focusing on one or two key notions disconnected from the general framework of their doctrine. For this reason I first outlined Eckhart's thought in general before expounding his theology of the Image.

The relation between God and creation can be characterised as "asymmetric identity": God as intellect is beyond being, and yet being is God; creaturely perfections are divine in nature-for creatures in themselves are nothing-and yet God is fundamentally unlike his creation. Thus Eckhart stresses both the radical dependence of creatures on God and the absolute otherness of God, a conviction shared by other negative theologians. Only the intellect is connatural with the divinity.

In the second part of our exposition of Eckhart's doctrine we investigated in more detail the role of the intellect as Image of God. We observed that Eckhart seems to obfuscate the distinction between the generation of

141. Rg.I.100. The ghedachte is the ground of the soul, closely related to the memory. As indicated earlier, this approach is in contrast with Eckhart who pays little attention to the memory and for whom the ground of the soul is intellectual in nature. In another passage, Ruusbroec, speaking of an inward life according to justice, writes: "Thus the person is just and goes to God with inner love by eternal activity; and he goes into God with enjoyable inclination, by eternal rest; and he abides in God and yet, he goes out to all creatures in a common love [in ghemeynre minne], in virtues and in justice. And this is the summit of the inner life. All the people who do not possess rest and activity have not obtained this justice." (Br.b 2274-80). 
the Son within the Trinity on the one hand and both God's creative and re-creative act on the other. He asserts the identity of the divine ground and the soul's ground, of the birth within the Trinity and within the soul. The problem is not the affirmation of identity as such (we could understand such statements as expressing an indistinguishableness), but the connaturality which supports this assertion. There is no distinction between the Word and the soul insofar as it is intellect. When Eckhart appeals to the Neoplatonic principle of the redditio completa to explain how the soul can participate in the return of the intellectual nature upon itself, the reader is left wondering whether this teaching can be reconciled with a theology of grace. I drew the reader's attention to the fact that occasionally more traditional teaching can be found in Eckhart's writings, but his more distinctive and original ideas are not shared by Ruusbroec. (Neither is there any evidence to suggest that Ruusbroec is indebted to Eckhart for the traditional teaching they occasionally share.) ${ }^{142}$

However, this is not the place to evaluate Eckhart's orthodoxy; I only want to indicate that Ruusbroec's writings are free from the ambiguities that characterize Eckhart's works. Ruusbroec is careful to state the difference between the generation of the Son and God's free act of creation; between our uncreated life as Idea in the Son and our created life; and finally, between the soul as made to the Image and the Son as the Image of the Trinity. Ruusbroec has a refined sacramental theology and a sophisticated Christology in which the life and humanity of Christ receive due attention. This seems another Franciscan element in his thought, quite alien to that of the Dominican Meister.

Ruusbroec situates the ground of the soul in the ghedachte or Augustinian memory, while he reserves the notion of the sparkle of the soul for the will, in contrast with Eckhart who repeatedly uses these concepts to denote the intellect. Seeing that Ruusbroec explicitly rejects any connaturality between God and soul he stresses the importance of grace. Therefore it comes as no surprise to find that he adopts the distinction between image and likeness, again in marked contrast with Eckhart.

However, there is an even more fundamental difference between our two authors. Ruusbroec's significance lies in the fact that he is an original trinitarian thinker. The notion of regyratio permeates his whole thought. The Spirit is an active principle through which the divine Persons flow back with enjoyment into their shared unity from where they go out again in a never-ending dynamic of ebb and flow. Although I suggested that Ruusbroec's trinitarianism shares some essential features with that of Bonaventure (fecundity of divine nature, primacy of the Father, exemplarism), this central notion of regyratio makes his thought quite unique within the Chris-

142. Even a charitable interpretation cannot obscure the bare fact that Eckhart's Christology is underdeveloped and his sacramental theology almost nonexistent. 
tian tradition. It also qualifies his understanding of the nature of love, as I tried to make clear by contrasting his thought with that of Richard of St. Victor.

Furthermore, it is revealing to compare the notion of regyratio with that of redditio completa. In Ruusbroec's view the regyratio occurs through the Spirit, the mutual Love of Father and Son. The redditio completa is the return of the Intelligible principle upon itself (the Son flows back to the Father) in which no role is ascribed to the Spirit; because of the connaturality of the human and divine intellect the soul can return to the Father and penetrate even further beyond the Persons in the Godhead, whereas in Ruusbroec's view the soul can participate in its eternal life as Idea within the Trinity (traditional exemplarism) after having been transformed through grace. As said earlier, he explicitly rejects the idea that this could be a natural process.

In short, behind a shared vocabulary (birth of the Son in the soul, Image theology, sparkle of the soul, ground of the soul, and so on) lies veiled two very different theologies. Some of Ruusbroec's main tenets appear to be rather Franciscan in inspiration, mainly in his trinitarian thought, Christology (focus on humanity and divinity of Christ), and even anthropology (in Ruusbroec's doctrine the intellect is not given the dominant role it holds for the Dominican Meister)—although he develops especially the first area in a highly original way (Holy Spirit as active principle of regyratio).

Eckhart's and Ruusbroec's understanding of exemplarity and theology of the Image are radically different. Whereas Eckhart's doctrine centers around the connaturality of the divine and human intellect, nothing of that sort can be found in Ruusbroec's writings. Their different theologies result in distinct spiritual aims: detachment for the German Preacher, the Common Life for the Prior of Groenendaal. For all these reasons, I consider it inappropriate to situate Ruusbroec in the spiritual movement of which Eckhart has come to be regarded as the main exponent and representative. 
